HETA 96-0101-2476

\title{
Midland Steel Products Company
} Janesville, Wisconsin

\author{
Stephen S. Smith, M.S. \\ James D. McGlothlin, Ph.D., C.P.E \\ Susan E. Burt, M.Sc., M.S.N \\ Randy L. Tubbs, Ph.D.
}




\section{Preface}

The Hazard Evaluations and Technical Assistance Branch of NIOSH conducts field investigations of possible health hazards in the workplace. These investigations are conducted under the authority of Section 20(a)(6) of the Occupational Safety and Health Act of 1970, 29 U.S.C. 669(a)(6) which authorizes the Secretary of Health and Human Services, following a written request from any employer or authorized representative of employees, to determine whether any substance normally found in the place of employment has potentially toxic effects in such concentrations as used or found.

The Hazard Evaluations and Technical Assistance Branch also provides, upon request, technical and consultative assistance to Federal, State, and local agencies; labor; industry; and other groups or individuals to control occupational health hazards and to prevent related trauma and disease. Mention of company names or products does not constitute endorsement by the National Institute for Occupational Safety and Health.

\section{ACKNOWLEDGMENTS AND AVAILABILITY OF REPORT}

This report was prepared by Stephen Smith and James McGlothlin, of the Engineering Control Technology Branch, Division of Physical Sciences and Engineering (DPSE), and by Susan Burt and Randy Tubbs of the Hazard Evaluations and Technical Assistance Branch, Division of Surveillance, Hazard Evaluations and Field Studies (DSHEFS). Figure illustrations by Daniel Watkins and Donald Murdock of the Engineering Control Technology Branch, Division of Physical Sciences and Engineering (DPSE). Desktop publishing by Kathy Mitchell.

Copies of this report have been sent to employee and management representatives at the Midland Steel Products Co. and the OSHA Regional Office. This report is not copyrighted and may be freely reproduced. Single copies of this report will be available for a period of three years from the date of this report. To expedite your request, include a self-addressed mailing label along with your written request to:

\section{NIOSH Publications Office \\ 4676 Columbia Parkway \\ Cincinnati, Ohio 45226 \\ 800-356-4674}

After this time, copies may be purchased from the National Technical Information Service (NTIS) at 5825 Port Royal Road, Springfield, Virginia 22161. Information regarding the NTIS stock number may be obtained from the NIOSH Publications Office at the Cincinnati address.

For the purpose of informing affected employees, copies of this report shall be posted by the employer in a prominent place accessible to the employees for a period of $\mathbf{3 0}$ calendar days. 


\title{
Health Hazard Evaluation Report 96-0101-2476 Midland Steel Products Company Janesville, Wisconsin February 1997
}

\author{
Stephen S. Smith, M.S. \\ James D. McGlothlin, Ph.D., C.P.E \\ Susan E. Burt, M.Sc., M.S.N \\ Randy L. Tubbs, Ph.D.
}

\section{SUMMARY}

On April 22-24, 1996, researchers from the National Institute for Occupational Safety and Health (NIOSH) conducted an evaluation of musculoskeletal disorders of the upper limbs and back associated with work at Midland Steel Products, a truck frame assembly plant. The objectives of this evaluation, requested by company management, were to: a) identify which jobs posed the greatest risk for musculoskeletal disorders and disease; and b) conduct an ergonomic evaluation of these jobs.

Based on confidential medical interviews, a review of company records, and the Occupational Safety and Health Administration (OSHA) Log and Summary of Occupational Injuries and Illnesses (Form 200) from 1989-1995, notable health problems of this workforce were upper extremity musculoskeletal disorders, low back pain, and hernias. Some discrepancies, usually in the amount of lost and restricted work time, were noted between OSHA 200 logs and information from other records provided by the company and information obtained during interviews. Incidence rates for disorders associated with repeated trauma (DART) and for low back pain or injuries involving lost work time exceeded average rates for this industrial sector.

Job analyses of the truck frame assembly and cross member fabrication operations showed that workers in these jobs were subjected to a combination of forceful exertions, and repetitive and sometimes awkward postures while fastening rivets and accessories, and reaming holes into the frame. Pulling and lifting the rails upright for cross member attachment and handling other frame attachments involve awkward postures of the back, as well as the lower and upper extremity. The use of some of the bolting, riveting, and reaming tools also involve potential upper extremity strain due to the tool weight and the orientation of the tool handle, which places the wrist in a deviated posture during many tasks.

On the basis of worker interviews, review of medical records, and job analysis information collected during this evaluation, NIOSH researchers determined that the potential for injuries to the back and upper extremity exists among the truck frame assembly line workers. Forceful exertions, external mechanical stress, repetitive work cycles and extended reaches during manual handling of material and tools are the primary risk factors. The use of lifting devices, improving the conveyor delivery system, repositioning equipment, and reorientating tool handles should reduce the risk of musculoskeletal injuries and illnesses among workers on the assembly line. Recommendations to reduce the risk of musculoskeletal stress, along with guidelines for establishing an ergonomics program, are included in this report.

Keywords: SIC 3714(Motor vehicle parts and accessories), Musculoskeletal Disorders, Manual Materials Handling, Cumulative Trauma Disorders, Automotive Manufacturing, Ergonomics, Workstation Design, Engineering Controls. 


\section{TABLE OF CONTENTS}

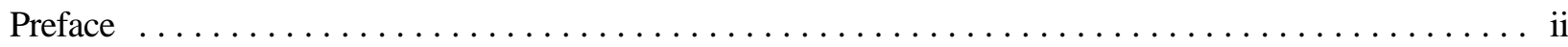

Acknowledgments and Availability of Report $\ldots \ldots \ldots \ldots \ldots \ldots \ldots \ldots \ldots \ldots \ldots \ldots \ldots \ldots \ldots \ldots \ldots \ldots$

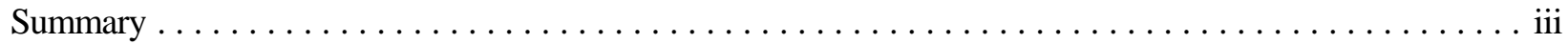

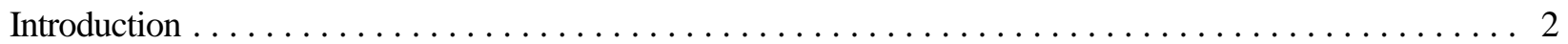

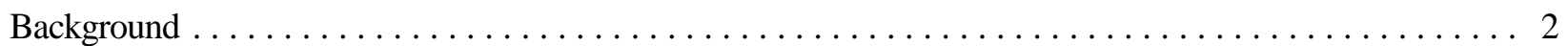

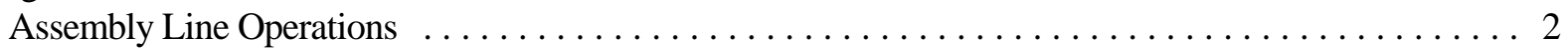

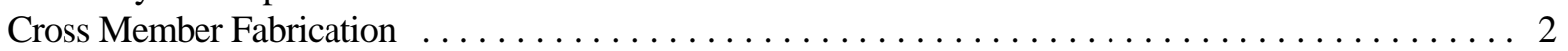

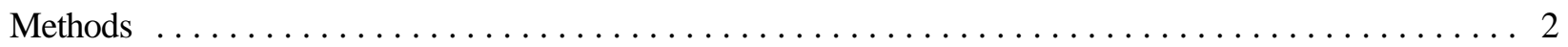

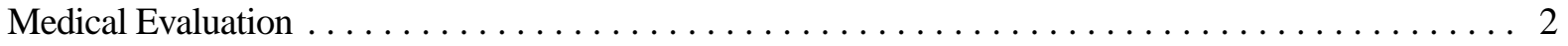

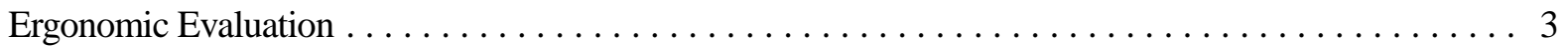

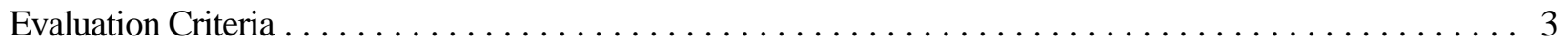

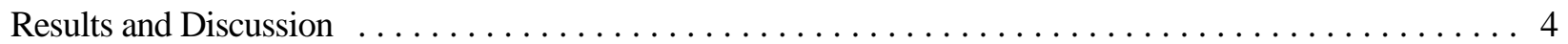

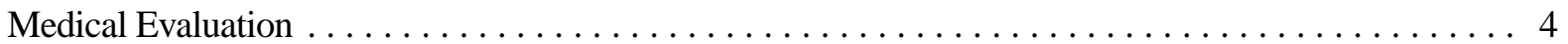

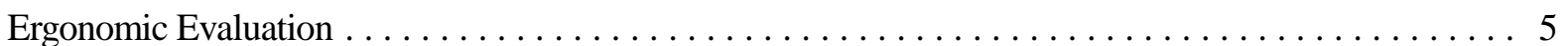

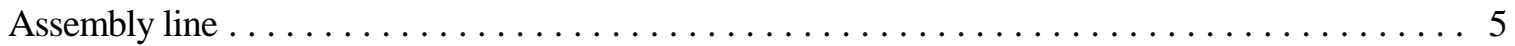

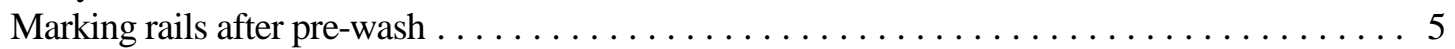

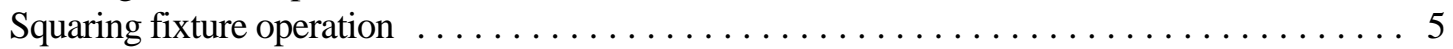

Rear suspension hangers and 1070 Station, Shock tower, Axle bracket $\ldots \ldots \ldots \ldots \ldots 6$

Overlapping stations - Toe hook/Bumper bracket/Huck stand, Rear engine bracket/Front rear hanger,

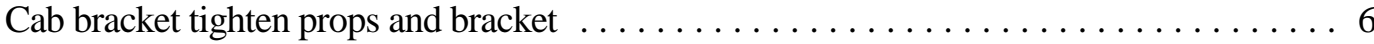

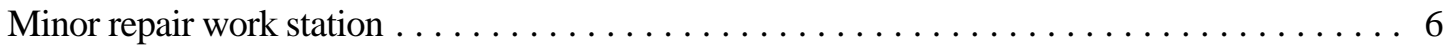

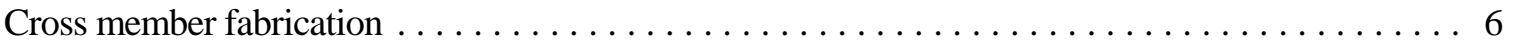

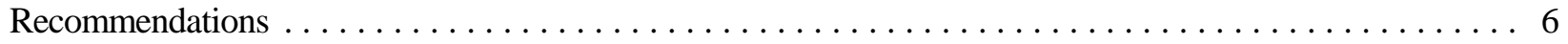

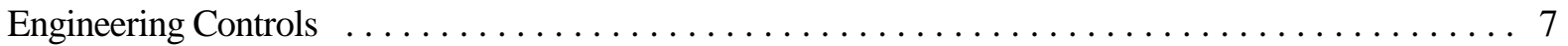

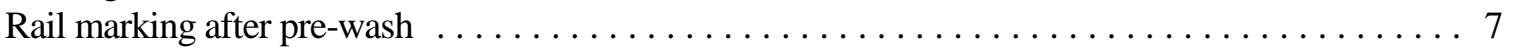

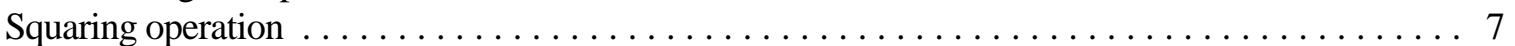

Toe hook/Bumper bracket/huck stand; Minor repair $\ldots \ldots \ldots \ldots \ldots \ldots \ldots \ldots \ldots$

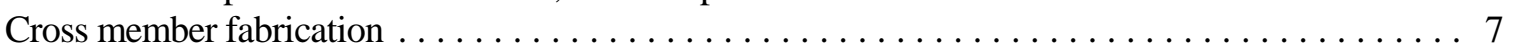

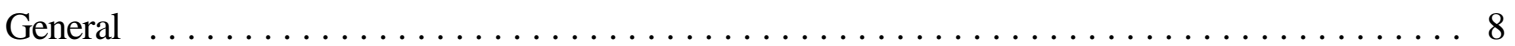

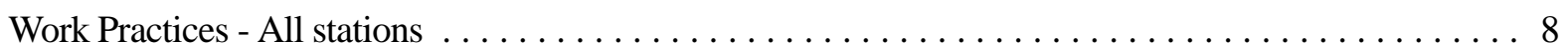

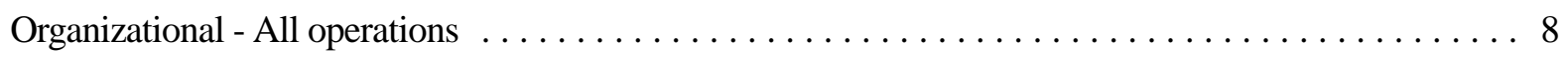

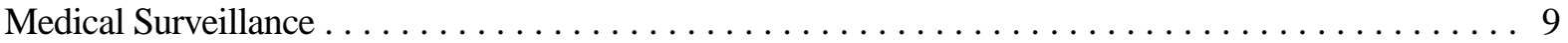

References ..................................... 10 


\section{INTRODUCTION}

On March 6, 1996, NIOSH researchers received a health hazard evaluation (HHE) request from management at the Midland Steel Products Company truck frame assembly plant in Janesville, Wisconsin. The request was for an ergonomic assessment of various jobs within the assembly area. The request was prompted by a concern of musculoskeletal disorders to workers in the assembly line area. NIOSH researchers conducted an on-site evaluation on April 22-24, 1996. The NIOSH evaluation focused on the assembly operation, as well as the cross member fabrication work.

\section{BACKGROUND}

This is a truck frame assembly plant that currently employs 47 production workers on a 10 -hour work shift. At the time of this evaluation there were 24 workers on the assembly line, while 2 workers were in the cross member fabrication area. The rate of production allows for approximately one shipment an hour of truck frames. The assembly process is divided into the following work stations:

Loading of Rails onto Conveyor

Grinding and Spot Welding

Beatty ${ }^{\mathrm{TM}}$ Machine Rail Processing Area

Initial Rail Preparation after Pre-Wash (Fifth Wheel Operation)

Squaring Fixture Operation

Rear Suspension Hangers

1070 Station, Shock Tower, Axle Bracket

Toe Hook/Bumper Bracket/Huck Stand

Rear Engine Bracket/Front Rear Hanger

Cab Bracket Tighten Props and Brackets

Minor Repair

Transfer Crane

Sub-Assembly (Cross Member Fabrication)

Although each station required specific tasks, there was some task overlapping with certain stations. The grinding and spot welding area as well as the cross member fabrication area are separate from the assembly line, but produce essential components for the line.

\section{Assembly Line Operations}

The assembly process begins once rails emerge from the hole punch Beatty ${ }^{\mathrm{TM}}$ and pre-wash machines. Starting with the squaring operation, an equal number of employees are located on either side of the conveyor. As the conveyor transports the rails down the line, employees attach cross members, brackets, hangers, and other components of the frame. The basic task elements for each assembly line station are shown in Table 1.

\section{Cross Member Fabrication}

There are two employees working in this area. This job consists of four basic manual tasks. Component pieces are retrieved from specific bins. The pieces are then placed on a stand and secured with a vise. An overhead rivet or bolt press tool is then used to bolt these pieces together. The cross member is then taken from the stand and placed into another bin. The basic task elements to perform this job are shown in Table 2.

\section{METHODS}

The evaluation consisted of a medical records review, confidential worker interviews, and an ergonomic evaluation of selected tasks on the assembly line and in the cross member fabrication area. These tasks were selected for evaluation based on the initial walk through survey on the morning of April 22, and conversations with management and employees about the jobs having a potential risk for musculoskeletal disorders.

\section{Medical Evaluation}

The medical evaluation included a review of the Occupational Safety and Health Administration 
(OSHA) Log of Occupational Injuries and Illnesses (Form 200), workers' compensation claim records, and confidential interviews with employees. Interviews focused on work history, work-related musculoskeletal symptoms, medical treatment, and employees' suggestions for improving work conditions.

Incidence rates for musculoskeletal disorders in the assembly department were calculated using OSHA log data for 1990-95 and compared to industry rates published by the Bureau of Labor Statistics. ${ }^{1}$ Included in this category are disorders due to repeated motion, carpal tunnel syndrome, synovitis, tendinitis, and bursitis. Incidence rates were calculated for each year by dividing the number of musculoskeletal cases by the number of full-time employees.

\section{Ergonomic Evaluation}

Videotapes of workers performing tasks on the line and in the cross member fabrication area were analyzed at regular speed to determine job cycle time, slow-motion to determine the risk of musculoskeletal stress during manual material handling tasks, and stop-action to identify job task elements and evaluate working postures. Video analysis procedures were used to document potential musculoskeletal hazards in performing the job.

Time and motion study techniques were used for the first phase of job analysis. ${ }^{2}$ Work methods analysis was used to determine the work content of the job. The second phase of job analysis was to review the jobfor recognized occupational risk factors for workrelated musculoskeletal disorders (WRMDs). These WRMDs risk factors include high repetition rate, high force, awkward posture, contact stress, low temperature, and vibration. ${ }^{3}$ This two-phase approach for job analysis and quantification of forces which act upon the body during materials handling forms the basis for proposed engineering and administrative controls aimed at reducing the risk for musculoskeletal stress and injury.

Work analysis also included an observational survey of potential exposure to detrimental hand-arm vibration. Jobs on the assembly line and in the cross member fabrication area requiring the use of hand held power tools were reviewed. Qualitative assessments of these jobs were performed for evidence of potential vibration energy transmittal to the worker. If the coupling between the worker and the tool was determined to allow transmission of vibration energy, then the duration of exposure was subsequently reviewed.

\section{Evaluation Criteria}

Work-related musculoskeletal disorders are the result of strain to a worker's musculoskeletal tissue from physical stress associated with job risk factors. WRMDscan occur in workers that perform job tasks requiring manual force, repetitive exertions, and stressful or awkward postures. ${ }^{4}$ Case reports have suggested certain occupational risk factors for musculoskeletal disorders. ${ }^{5,6,7,8}$ Epidemiologic studies have identified associations between job factors (such as repetition, awkward postures, and force) and musculoskeletal disorders., ${ }^{9}, 10,11,12,13,14$ While more studies are needed to quantify the relationship between job risk factors and musculoskeletal disease, available data demonstrates a relationship between certain job risk factors and musculoskeletal disorders.

WRMDs of the upper limbs have been associated with job tasks that include: (a) repetitive movements of the upper limbs; (b) forceful grasping or pinching of tools or other objects by the hands; (c) awkward positions of the hand, wrist, forearm, elbow, upper arm, shoulder, neck, and head; (d) direct pressure over the skin and muscle tissue; and (e) use of handheld vibrating tools. Because some of these activities or actions are part of required tasks in many service and industrial work, occupational groups are at risk for potentially developing WRMDs of the upper limbs. Occupational risk factors for low back injuries include manual handling tasks, ${ }^{15}$ twisting, ${ }^{16}$ bending,${ }^{16}$ falling, ${ }^{17}$ reaching ${ }^{18}$ lifting excessive weights, ${ }^{16,19,20}$ prolonged sitting, ${ }^{17}$ and vibration. ${ }^{16,21}$ 
Redesign of jobs can lead to the reduction of risk factors and prevention of back injuries. Approaches such as job redesign and training may be the best methods for controlling back injuries and pain. ${ }^{22}$

\section{RESULTS AND DISCUSSION}

\section{Medical Evaluation}

During a telephone conversation with management representatives prior to the site visit, and during the opening conference on the first day of the site visit, NIOSH investigators requested that any employee who wanted to participate in a confidential medical interview be permitted to do so. NIOSH investigators also invited workers to be interviewed during a walk-through tour of the plant. During the site visit, a supervisor coordinated the release of workers from their job responsibilities to be interviewed. Confidential medical interviews were conducted with six men and five women. Their average age was 36 years (range, 30-46), and they had worked at the plant for an average of 4.6 years (range, 1-7). The interviewees reported the following musculoskeletal health problems that they attributed to employment at the plant: low back pain (5), hernia surgery (4), "knots" in navel or groin area (2), sprains/strains (4), shoulder injury/pain (3), elbow tendinitis that required cortisone injection (1), carpal tunnel release surgery (1), and wrist pain with finger numbness (2). Three of the four workers who had hernia surgery were using reamers at the time of hernia symptoms onset, and one was handling heavy material. Another reamer operator reported a "knot" in the navel area.

Entries on the OSHA $200 \log$ were reviewed for the 7 years that the plant has been in operation (July 1989 through April 1996). There were some discrepancies between the OSHA entries and the interviews. For example, four employees reported having surgery for work-related hernias, but only three hernias were recorded on the OSHA $200 \log$ : two in 1995, and one in 1993. Also, one log entry for a hernia had no lost work days recorded, although the employee reported six weeks lost work time following surgery. In another case, lost work days were recorded for another injury to that employee, but none were recorded in the log entry for the hernia. The company also kept a separate list for carpal tunnel syndrome (CTS) cases until 1991. According to this list, eight employees had undergone carpal tunnel surgery between January 1990 and January 1991. A ninth employee was scheduled for carpal tunnel surgery in April 1991, but it is unclear whether the surgery was performed. Five of these employees had bilateral carpal tunnel surgery. Four other employees on the list were apparently diagnosed with CTS in 1990, but did not have surgery. There were discrepancies in the amount of lost work time and restricted work time between the company's CTS list and the OSHA 200 $\log$. The company's list consistently showed longer amounts of lost and restricted work time than was recorded on the OSHA $200 \log$.

The annual OSHA log entries that meet the criteria for "Disorders Associated with Repeated Trauma" $(\text { DART })^{1}$ are presented in Table 3 for each full year that the plant has been in operation. Tendinitis and carpal tunnel syndrome should be included, according to OSHA criteria, but not sprains and strains. In the opinion of the NIOSH investigator, some log entries should have been included in column 7f (DART) that were not. Table 3 shows the NIOSH investigator's counts alongside the number of entries that were recorded in column $7 \mathrm{f}$ (DART) on the log. Incidence rates for DART exceeded the average for this industrial sector, regardless of whether the NIOSH investigator's counts or the number of cases as recorded on the OSHA $200 \log$ were used in the calculations.

OSHA $200 \log$ entries for back pain/injuries are presented in Table 4. These are not recorded under column 7 f on the log, according to OSHA guidelines, which state: "Back cases should be classified as injuries because they are usually triggered by an instantaneous event." $\log$ entries for episodes of upper extremity pain differ from those for episodes of back pain because more than one log entry may 
appear for the same individual for episodes of back pain, while multiple entries for recurring pain at the same site do not appear for the same individual if the entry is recorded under column 7f, DART. In at least eight cases, the same individuals had at least two entries on the logs for back pain/injuries. In some cases, there were repeat back pain/injury entries within the same year. For example, in 1995, two individuals had two entries each for back pain/injury, and one individual had three entries for back pain/injury during the year. In comparison, there are no repeated entries for the same individual in Table 3 , unless a different body location was involved. For the years that industrial sector comparison rates were available, back pain/injury rates exceeded the average.

\section{Ergonomic Evaluation}

\section{Assembly line}

\section{Marking rails after pre-wash}

Table 5 highlights the job musculoskeletal stressors and recommended changes to decrease these stressors for specific job task elements. Placing attachments onto rails may contribute to stress on the wrists, arms, and shoulders. Having to extend the arms when holding and raising attachments creates a biomechanical disadvantage and requires more muscular effort. The task of manually placing washers onto bolts may be a source of musculoskeletal stress to the hands and wrists. The repetitiveness of the task, and the use of a pinch grip, may contribute to musculoskeletal fatigue and strain.

The potential for strain to the hands and wrists can be reduced by providing a "centrifuge" style container that attaches bolts to the positioned washer. As the container operates the bolts can be fed to a positioned washer.

\section{Squaring fixture operation}

The major stresses occur during the initial pulling and lifting of the rails, lifting cross members from bins, placing cross members into position, and manipulating the rivet press tool (anvil). The posture and exertion required to complete these assembly tasks may increase musculoskeletal stress and fatigue to the worker. Due to the design of the assembly line, the worker usually performs the reaching, pushing, pulling, and piece positioning asymmetrically, which may compound the stress on one side of the worker's body. This type of asymmetric material handling technique is employed when lifting rails and positioning certain cross members between the rails. The manual lifting of rails and "slamming" of cross members between the rails may be inflicting hazardous biomechanical loading to the arms, shoulders, and back. Modification of the conveyor to deliver the rails already in an upright position will eliminate the requirement for manual rail lifting. Also having the conveyor flare the rails away from the center will allow certain cross members to be placed into position prior to rail delivery. This type of modification will eliminate the current need for "slamming" certain cross members into position between rails. Figure 1 is a conceptual example of such a conveyor system.

The torso flexion often required to retrieve cross members from bins may result in potentially hazardous biomechanical loading of the lower back. Bending and reaching at the torso for lifting cross members out of the bins requires more muscle exertion, primarily at the lower back, to compensate for the increase in load. Modifying the dimensions of the bin as well as having the bin on an adjustable tilt stand will bring the contents closer to the worker and reduce the extent of torso flexion when reaching into the bin. The introduction of a cross member delivery system will prevent workers from having to reach in and lift cross members and other attachments out of bins.

Musculoskeletal stress may also occur when manipulating the "anvil." Once the rails are upright and cross members are in position, rivets are placed in corresponding holes. The anvil is then used to fasten the cross members to the rails by manually positioning it on each rivet, and one at a time 
pressing the rivets into place. Although the anvil is on a trolley system, its weight of $500 \mathrm{lbs}$. necessitates a certain amount of force to maneuver into position. Risk to the workers' shoulders and back can be compounded if the anvil is out of balance and/or if the trolley efficiency has been compromised. Improving anvil balance and the trolley system will reduce the amount of effort required to manipulate such a tool. This particular tool, as with other tools used in the plant, was determined not to pose a vibration exposure problem to the workers. The NIOSH investigators also considered the potential for exposure to vibration from handling the "anvil." It was determined that neither the anvil nor any other tools used in assembly at the plant presented any vibration exposure problems.

\section{Rear suspension hangers and 1070 Station, Shock tower, Axle bracket}

The musculoskeletal stressors to the hands, wrists, arms, shoulders, and back are from reaching into bins and the middle of the conveyor to retrieve hangers and fastening components. The weight of the hangers (10 to $25 \mathrm{lbs}$.), along with having to bend and reach, requires workers to exert more effort, potentially increasing stress to musculoskeletal tissue. Introducing a parts delivery system will alleviate the musculoskeletal stress on the worker from having to reach and lift the hangers and other components. As in the squaring operation, musculoskeletal stress may also occur when manipulating the "anvil."

\section{Overlapping stations - Toe hook/Bumper bracket/Huck stand, Rear engine bracket/Front rear hanger, Cab bracket tighten props and bracket}

Musculoskeletal stressors to the hands, wrists, arms, shoulders, and back associated with these stations are similar to those described with the 1070 station. Although the anvil is not required at these stations, workers do use a reamer to modify existing frame holes or to create new ones. The main musculoskeletal stressor to the lower torso, back, and extremities is from having to lean against the reamer while it is in operation. Significant external mechanical stress to the worker's lower torso/hip region is due to the amount of force necessary to penetrate the frame and to maintain tool stability. Such a level of stress may result in damage to the workers' musculoskeletal tissue. The fact that three of the four employees who reported having hernia surgery were using reamers at the time of onset is consistent with these ergonomic observations. Although there does not seem to be significant exposure to vibration, the reamer bit occasionally becomes caught in the frame causing the worker to intermittently jerk with the tool. The extent and power of such jerking is dependent upon the coupling between the worker and the reamer, reamer bit efficiency, and frame material integrity. This type of external mechanical stress to the worker can be reduced by introducing a levering mechanism that will allow the reamer to be positioned mechanically. Figure 2 is a conceptual example of such a mechanism.

\section{Minor repair work station}

The musculoskeletal stressors to the hands, wrists, arms, shoulders, and back associated with these stations are similar to those described above.

\section{Cross member fabrication}

Table 6 highlights the stressors observed during cross member fabrication and the recommended changes to decrease these stressors respectively. The main musculoskeletal stresses to the upper limbs and back occur during retrieval of cross member pieces from bins, as well as when carrying and placing fabricated cross members into bins. The potential for musculoskeletal stress and fatigue is due to the bending and reaching posture required to grab and lift material from bins. The NIOSH evaluators observed the workers performing torso flexion beyond ninety degrees and/or adopting an asymmetric lean posture. These types of postures require an increase in force/exertion to lift or handle material. Reducing the reach and carrying distance will reduce the biomechanical stress on the worker. This can be accomplished by providing a bin with a 
spring-loaded bottom on a tilted platform, which raises the material as quantity decreases. A conveyor system from the vise stand to a bin will eliminate the necessity of carrying the finished product to the bin. Figure 3 contains examples of bin, platform, and conveyor system design.

\section{RECOMMENDATIONS}

Since work-related musculoskeletal disorders (WRMDs) can be associated with many factors, successful control and prevention of WRMDs require a multifactorial approach. The following recommendations include engineering controls, administrative controls, education and training, and a medical program. All of these measures should be part of an ergonomics program that includes input from employees as well as management and consultants.

\section{Engineering Controls}

\section{Rail marking after pre-wash}

Use a container handling device that will mechanically (automatically, pneumatically, etc.) place washers onto bolts. One possibility is a centrifuge-type of parts handler. The bolts would be sorted automatically and delivered through a slot. Simultaneously, a washer would be slid into position at the face of the slot. As the bolt slides down the slot it will go through the positioned washer and fall into a container. This will reduce the amount of fine hand work needed to attach small fastening components. This type of centrifuge parts handler is commercially available.

\section{Squaring operation}

- Modify the conveyor to deliver the rails onto rollers that rotate them upright. Guide and positioning posts should allow rails to be delivered upright and away from the center (Figure 1). A portion of these posts can be designed to move hydraulically perpendicular to the linear direction of the conveyor. Activation of the posts will bring the rails towards the center. This will allow some cross members to be placed into proper position before the rails are delivered. Once the cross members are in place the rails would be automatically brought to the center.

The flaring out of the rails does not have to be too far, just enough to clear cross members already in position. This may be accomplished by increasing the width of the conveyor from the pre-wash. As the rails gradually tilt upwards, they will slide perpendicular to the direction of transport. The sliding rails will only go as far as the width of the conveyor. If the conveyor is wide enough, then the rails will be brought to the guides with sufficient clearance of the cross members already in position. This type of conveyor system will eliminate having to manually lift the rails, as well as "swinging" and "slamming" some cross members into position.

- Introduce a cross member delivery system that will prevent having to lift the cross members and other attachments out of the bins. The bin design may require modifications that allow it to be mechanically lifted and/or tilted. These types of modifications will decrease the amount of bending and reaching and improve the accessibility to materials in the bin. Vendors are able to customize such a parts delivery system.

\section{Toe hook/Bumper bracket/huck stand; Minor repair}

Develop or introduce a mechanism that will allow the worker to position and press the reamer onto the frame mechanically. This type of reamer apparatus could hang overhead or be attached to the conveyor system (Figure 2). The apparatus could clamp to the frame and the reamer bit would be pressed to the frame. The apparatus would be designed to redirect the torque generated during operation away from the worker. This type of setup will alleviate the manual force necessary to press the reamer into place and 
control it during operation.

Also provide cushioned reamer handles. Cushioned handles will relieve some of the external mechanical stress to the worker's hands and hip region.

\section{Cross member fabrication}

- Develop and/or provide a bin with a springloaded bottom on an adjustable platform. A spring-loaded bottom will raise the material as the quantity in the bin decreases. Also, the adjustable platform should allow tilting and raising of the bin to the worker's specifications. This type of bin load manipulation and adjustability should alleviate excessive leaning and bending during retrieval of the product.

- Provide a conveyor system from the vise stand to the bin for finished cross members. The system can incorporate rollers, or it can involve an overhead trolley that is attached to the cross member. This type of setup should alleviate the continuous manual lifting and carrying of finished cross members. The finished product bin should also be adjustable to prevent excessive leaning, bending, and reaching during product placement (Figure 3 ).

- Provide a grip on the anvil such that the employee can maintain a neutral wrist posture. The grip should have at least two degrees of freedom of adjustability. This modification will enable the worker to adjust the grip to the most comfortable and least stressful orientation.

\section{General}

- Re-arrange the process so that the Beatty ${ }^{\mathrm{TM}}$ operation is performed after heat treatment. This may decrease the amount of hole misalignment due to unequal material expansion. A decrease in hole misalignment should result in a decrease in the amount of reamer use.

- Introduce a practical parts delivery system for each station. The system could consist of a stand with an angled roller fitted chute that allows parts or components to slide into position close to the worker. This type of arrangement will prevent the worker from having to reach and lift components out of bins and/or from the middle of the conveyor.

- Reevaluate bin dimension requirements and construction style. The current design and dimensions may be forcing workers to assume awkward postures when removing material from and/or placing material into the bin(s).

- Provide bottom-spring-loaded bins for those operations which require obtaining pieces from a bin as part of the work cycle. A spring-loaded bin will bring the remaining pieces closer to the worker as the top pieces are removed. This should relieve the worker from having to reach excessively into the bin as the bin load decreases.

- Provide cushioned, heat resistant floor mats for those having to stand for more than 50 percent of their shift. The floor mats should provide sufficient traction despite having lubricant spilled on them. The edges of the floor mats should be beveled to reduce tripping hazards.

\section{Work Practices - All stations}

- For those stations required to use the anvil, determine if it is necessary to lean and press into the anvil once it is in position. If leaning into the anvil is determined unnecessary, then some external mechanical pressure to the shoulder and chest regions will be relieved.

- If possible, have workers performing similar tasks on opposite sides of the conveyor rotate to alternate sides several times each work shift. This practice will decrease the duration of stress to one side of the worker's body.

\section{Organizational - All operations}


- Establish or strengthen written ergonomics program. Attempting to augment an injury reduction program, management and labor must be diligent in their approach to control injuries. ${ }^{23}$ Guidelines for establishing an effective ergonomics program within a plant are mentioned in Appendix A.

- Reevaluate and, if necessary, strengthen the within plant tool maintenance program. Establish a feasible tool maintenance schedule involving periodic tool reliability and durability checks. A tool working properly may alleviate some musculoskeletal stress to the worker. For example, the proper balance of the anvil and a sharp reamer bit will prevent the increase of manual force required to operate these tools. Also, a properly maintained tool will reduce lubricant leakage, resulting in a reduction in slipping hazards.

- Continue periodic job rotation within or between operations. Job rotation and job enlargement should enable the worker to use different muscle groups.

- Train workers about ergonomic principles to reduce musculoskeletal hazards in their area. Experienced workers can demonstrate work practice techniques to reduce musculoskeletal strain on the body and teach job performance techniques that optimize movement and function. For example, experienced workers could discuss techniques for using the anvil.

- Strengthen general plant housekeeping programs. Constant emphasis on cleaning lubricant spills and removing debris from floors will help provide a safe work environment for the entire plant.

- Reevaluate the overtime scheduling procedures. Some of the employees interviewed reported working 65 hours per week. Discuss the overtime situation with employees and, if it is a problem, discuss possible solutions.

\section{Medical Surveillance}

- Improve the medical and OSHA $200 \log$ record keeping system. Accurate and diligent maintenance of injury/illness information will help identify problem areas, as well as track results from any implemented engineering and/or administrative controls.

- Develop a medical surveillance program for musculoskeletal disorders. Early detection of problems will complete the communication cycle between workers and management to avoid more serious musculoskeletal disorders. Medical surveillance can be active or passive. Active surveillance is usually conducted by administering standardized questionnaires to workers in problem and non-problem jobs. Passive surveillance is conducted by examining medical injury or illness records, such as OSHA 200 logs, workers' compensation reports, and attendance records for absenteeism. Analysis is done on both approaches to determine patterns of injury and changes in these patterns, either by increases or decreases, over time. 


\section{REFERENCES}

1. U.S. Department of Labor, Bureau of Labor Statistics: Recordkeeping Guidelines for Occupational Injuries and Illnesses. U.S. Government Printing Office: 1986-491-543:54422.

2. Barnes, R [1972]. Motion and Time Study, Design, and Measurement of Work. New York, NY: John Wiley and Sons.

3. Armstrong, TJ and Silverstein BA [1987]. Upper-Extremity Pain in the Workplace-Role of Usage in Casualty. Clinical Concepts in Regional Musculoskeletal Illness. Grune and Stratton, Inc: 333-354.

4. Putz-Anderson V [1988]. Cumulative trauma disorders: A manual for musculoskeletal diseases of the upper limbs. Bristol, PA: Taylor \& Francis.

5. Conn HR [1931]. Tenosynovitis. Ohio State Med. J. 27: 713-716.

6. Pozner H [1942]. A Report on a Series of Cases on Simple Acute Tenosynovitis. J. Royal Army Medical Corps 78:142.

7. Hymovich L and Lindholm M [1966]. Hand, Wrist, and Forearm Injuries. J. Occup. Med. 8:575-577.

8. Wasserman D and Badger D [1977]. Eastman Kodak Company, Windsor, Colorado. Health Hazard Evaluation Report No. TA 76-93. U.S. Department of Health, Education and Welfare, Public Health Service, Center for Disease Control, National Institute for Occupational Safety and Health.

9. Anderson JAD [1972]. System of Job Analysis for Use in Studying Rheumatic Complaints in Industrial Workers. Ann. Rheum. Dis. 31:226.

10. Hadler N [1978]. Hand Structure and Function in an Industrial Setting. Arth. And Rheum. 21:210-
220.

11. Drury C and Wich J [1984]. Ergonomic Applications in the Shoe Industry. Proceedings Intl. Conf. Occup. Ergonomics, Toronto 489-493.

12. Cannon LJ, Bernacki EJ, and Walter SD [1981]. Personal and Occupational Factors Associated with Carpal Tunnel Syndrome. J. Occup. Med. 23(4): 225-258.

13. Armstrong TJ, Foulke JA, Bradley JS, and Goldstein SA [1982]. Investigation of Cumulative Trauma Disorders in a Poultry Processing Plant. Am. Ind. Hyg. Assoc. J. 43: 103-106.

14. Silverstein BA[1985]. The Prevalence of Upper Extremity Cumulative Trauma Disorders in Industry. Ph.D. Dissertation, University of Michigan.

15. Bigos SJ, Spenger DM, Martin NA, Zeh J, Fisher L, Machemson A, and Wang MH [1986a]. Back Injuries in industry: A Retrospective Study. Injury Factors. Spine 11: 246-251.

16. Frymoyer JW and Cats-Baril W [1987]. Predictors of Low Back Pain Disability. Clin. Ortho. And Rel. Res. 221: 89-98.

17. Magora A [1972]. Investigation of the Relation Between Low Back Pain and Occupation. Ind. Med. Surg. 41: 5-9.

18. U.S. Department of Labor, Bureau of Labor Statistics: Back Injuries Associated with Lifting. Bulletin 2144, August 1982.

19. Chaffin DB and Park KS [1973]. A Longitudinal Study of Low-Back Pain as Associated with Occupational Weight Lifting Factors. Am. Ind. Hyg. Assoc. J. 34: 513-525.

20. Liles DH, Dienvanyagm S, Ayoub MM, and Mahajan P [1984]. A Job Severity Index for the Evaluation and Control of Lifting Injury. Human Factors 26: 683-693. 
21. Burton AK and Sandover J [1987]. Back Pain in Grand Prix Drivers: A Found Experiment. Ergonomics 18: 3-8.

22. Snook SH [1987]. Approaches to the Control of Back Pain in Industry: Job Design, Job Placement, and Education/Training. Spine: State of the Art Reviews 2:45-59.

23. Liker JK, Joseph BS, and Ulin SS [1991]. Participatory ergonomics in two U.S. automotive plants. Chapter 6. In: Participatory Ergonomics, Edit by K. Noro, A. Imada. London: Taylor \& Francis.

24. McGlothlin JD, Armstrong TJ, Fine LJ,
Lifschitz Y, Silverstein B. [1984]. Can job changes initiated by a joint labor-management task force reduce the prevalence and incidence of cumulative trauma disorders of the upper extremity? Proceedings of the 1984 International Congress on Occupational Ergonomics, Toronto, Canada, Vol 1:336-340.

25. Gjessing CC, Schoenborn TF, and Cohen A. eds [1994]. Participatory Ergonomics Interventions in Meatpacking Plants. U.S. Department of Health and Human Services, Public Health Service, Centers for Disease Control and Prevention, National Institute for Occupational Safety and Health. DHHS (NIOSH) Publication No. 94-124. 
Table 1

HETA 96-0101

Midland Steel Products Co.

Janesville, Wisconsin

Description of task elements for jobs on the assembly line

\begin{tabular}{|c|c|}
\hline Basic Job Elements & Initial rail preparation after pre-wash \\
\hline 1. & Mark the rails using a type of chalk marker. \\
\hline 2. & Check specifications sheet, lay certain attachments on both rails. \\
\hline 3. & Roll up specification sheet and stick in opening of one of the rails. \\
\hline \multirow[t]{3}{*}{4.} & Return to table and continue attaching washers and bolts for eventual use. \\
\hline & $\begin{array}{l}\text { Piece weight: The weight of the attachments varied (10-20 lbs.). Work cycle time: 15-20 } \\
\text { seconds. }\end{array}$ \\
\hline & Squaring Operation \\
\hline 1. & Grab rail and pull down into appropriate position along the line. \\
\hline 2. & Set rail and check to make sure each worker has a grasp of rail and ready to lift. \\
\hline 3. & $\begin{array}{l}\text { The workers simultaneously lift and rotate the rail upright against posts automatically set into } \\
\text { position. }\end{array}$ \\
\hline 4. & Turns, grabs and lifts cross member out of bin. \\
\hline 5. & Returns to line with cross member. \\
\hline 6. & Fits cross member into place, oftentimes swinging and slamming cross member. \\
\hline 7. & Fasten cross member to rails on either side of line with rivet press (Anvil). \\
\hline 8. & Attach other components to frame. \\
\hline 9. & Pull tools back out of the way and push frame towards next station. \\
\hline \multirow[t]{3}{*}{10.} & Wait for next set of rails. \\
\hline & $\begin{array}{l}\text { Rail weight: varied; Cross member weight: from } 15 \mathrm{lbs} \text {. to over } 40 \mathrm{lbs} \text {. Entire work cycle } \\
\text { time: approximately } 200 \text { seconds ( } 3 \mathrm{~min} .20 \mathrm{sec} \text {.). }\end{array}$ \\
\hline & Rear suspension hangers \\
\hline 1. & Wait for frame. \\
\hline 2. & Grab hangers and other components from bin. \\
\hline 3. & Grab fastening components from middle of conveyor. \\
\hline
\end{tabular}


Table 1 (Continued)

\begin{tabular}{|c|c|}
\hline 4. & Fasten attachments with either nutrunner or rivet press (Anvil). \\
\hline 5. & Check fastened joint. \\
\hline \multirow[t]{3}{*}{6.} & Maneuver tools out of the way and wait for next frame. \\
\hline & Hanger weight: 10 to $25 \mathrm{lbs}$. Work cycle time: Varied. \\
\hline & 1070 Station, Shock tower, Axle bracket \\
\hline 1. & Wait for frame. \\
\hline 2. & Grab attachments. \\
\hline 3. & Grab fastening components. \\
\hline 4. & Fasten attachments using rivet press (Anvil). \\
\hline \multirow[t]{3}{*}{5.} & Wait for next frame. \\
\hline & Attachment weight: 5 to $20 \mathrm{lbs}$. Work cycle time: varied from 1 to 2 minutes. \\
\hline & $\begin{array}{l}\text { Overlapping stations with similar tasks: } \\
\text { Toe hook/Bumper bracket/Huck Stand } \\
\text { Rear engine bracket/Front rear hanger } \\
\text { Cab bracket tighten props and brackets }\end{array}$ \\
\hline 1. & Wait for frame. \\
\hline 2. & Grab attachments. \\
\hline 3. & Grab fastening components. \\
\hline 4. & If necessary a reamer is used to adjust hole size and alignment, before initiating attachment process. \\
\hline 5. & Fasten attachments using nutrunners. \\
\hline \multirow[t]{3}{*}{6.} & Wait for frame. \\
\hline & Attachment weight: 5 to $15 \mathrm{lbs}$. Work cycle time: varied from 1 to 3 minutes. \\
\hline & Minor repair \\
\hline 1. & Check frame and specification sheet. \\
\hline 2. & If necessary ream the frame. \\
\hline 3. & Fasten attachments and/or adjust attachments, using nutrunner or rivet press tool. \\
\hline \multirow[t]{2}{*}{4.} & Check-off frame. \\
\hline & Attachment weight: varied. Work cycle time: varied from 1 to 3 minutes. \\
\hline
\end{tabular}


Table 2

HETA 96-0101

Midland Steel Products Co.

Janesville, Wisconsin

Description of job elements for the cross member fabrication area

\begin{tabular}{||l|l||}
\hline $\begin{array}{l}\text { Basic Job } \\
\text { Elements }\end{array}$ & Cross member fabrication \\
\hline \hline 1. & Grab larger cross member piece from bin. \\
\hline 2. & Secure piece on vise stand. \\
\hline 3. & Grab smaller cross member end pieces from another bin. \\
\hline 4. & Position end pieces with the larger piece. \\
\hline 5. & Grab rivets from box on stand and place into appropriate holes. \\
\hline 6. & Fasten pieces together with rivet press tool. \\
\hline 7. & Lift, carry, and place finished product into another bin. \\
\hline 8. & Return to larger cross member bin. \\
\hline & $\begin{array}{l}\text { Piece weight: larger piece - } 20 \text { to } 25 \text { lbs.; smaller pieces - } 10 \text { to } 15 \text { lbs. each; finshed product - } 30 \text { to } \\
40 \text { lbs. Work cycle time: approximately } 105 \text { seconds (1 min. } 45 \text { seconds). }\end{array}$ \\
\hline
\end{tabular}


Table 3

HETA 96-0101

Midland Steel Products Co.

Janesville, Wisconsin

Cases of disorders associated with repeated trauma (DART)

\begin{tabular}{|c|c|c|c|c|c||}
\hline Year & $\begin{array}{c}\text { \# DART } \\
\text { cases } \\
\text { (by NIOSH } \\
\text { investigator) }^{\mathrm{a}}\end{array}$ & $\begin{array}{c}\text { \# DART cases } \\
\text { (by company) }\end{array}$ & $\begin{array}{c}\text { \# Full- time } \\
\text { workers } \\
\text { by year }\end{array}$ & $\begin{array}{c}\text { Incidence rates }{ }^{\mathrm{b}}: \\
\text { \#DART/100 }_{\text {workers }}\end{array}$ & $\begin{array}{c}\text { Industry } \\
\text { (bIC 3714) }^{\mathrm{d}} \\
\text { incidence rate: } \\
\text { \#DART/100 } \\
\text { workers }\end{array}$ \\
\hline 1990 & 13 & 11 & 28 & $46.4(39.3)$ & 2.4 \\
\hline 1991 & 3 & 0 & 32 & $9.4(0)$ & 2.7 \\
\hline 1992 & 8 & 6 & 37 & $21.6(16.2)$ & 3.1 \\
\hline 1993 & 9 & 8 & 45 & $20.0(17.8)$ & 3.5 \\
\hline 1994 & 10 & 8 & 47 & $21.3(17.0)$ & 3.4 \\
\hline 1995 & 5 & 4 & 60 & $8.3(6.7)$ & not available \\
\hline
\end{tabular}

a Includes log entries that, in the opinion of the NIOSH investigator, should have been considered DART but were not.

b Rates calculated based on \# of employees and \# of DART cases determined by NIOSH investigator from a review of OSHA $200 \mathrm{logs}$. Numbers of hours worked was not available. The assumption is that each full-time worker works 2,000 hours per year. If employees work more hours, then rates would be lower.

c Rates in parentheses are based on the number of entries that were recorded under DART on the OSHA $200 \log$.

d Motor vehicle parts and accessories. 
Table 4

HETA 96-0101

Midland Steel Products Co.

Janesville, Wisconsin

\section{Back Injuries}

\begin{tabular}{||c|c|c|c|c||}
\hline Year & $\begin{array}{c}\text { \# Back Pain/Injury entries } \\
\text { on } \\
\text { OSHA 200 log }\end{array}$ & $\begin{array}{c}\text { Lost workday back injury } \\
\text { cases }\end{array}$ & $\begin{array}{c}\text { Lost workday back } \\
\text { injury incidence } \\
\text { rate/100 workers }\end{array}$ & $\begin{array}{c}\text { Industry (SIC } \\
\text { 3714) } \\
\text { workday back } \\
\text { injury incidence } \\
\text { rate/100 workers }\end{array}$ \\
\hline 1990 & 6 & 3 & 10.7 & not available \\
\hline 1991 & 6 & 2 & 6.3 & not available \\
\hline 1992 & 5 & 3 & 8.1 & 1.1 \\
\hline 1993 & 3 & 2 & 4.4 & 1.0 \\
\hline 1994 & 9 & 3 & 6.4 & 1.1 \\
\hline 1995 & 19 & 4 & 6.7 & not available \\
\hline
\end{tabular}

e Motor vehicle parts and accessories. 
Table 5

HETA 96-0101

\section{Midland Steel Products Co. \\ Janesville, Wisconsin}

Musculoskeletal stresses and recommendations for assembly line operations

\begin{tabular}{|c|c|c|}
\hline $\begin{array}{l}\text { Basic Job } \\
\text { Elements } \\
\text { from } \\
\text { Table } 1 \\
\end{array}$ & Problem & Recommendations \\
\hline & Rail Marking & \\
\hline \multirow[t]{2}{*}{$1-4$} & $\begin{array}{l}\text { Potential risk to shoulders from reaching to place } \\
\text { parts onto rails. } \\
\text { Potential stress to hands and wrists from repetitive } \\
\text { use of pinch grip while manually attaching nuts and } \\
\text { bolts. }\end{array}$ & $\begin{array}{l}\text { Use container handling device which will } \\
\text { mechanically (automatically, } \\
\text { pneumatically, etc.) attach nuts and bolts. }\end{array}$ \\
\hline & Squaring operation & \\
\hline \multirow[t]{2}{*}{$1-10$} & $\begin{array}{l}\text { Risk to upper extremity and back from pulling the } \\
\text { rails into position. } \\
\text { Risk to upper extremity and back from lifting rails } \\
\text { upright, lifting cross members from bins, 'swinging' } \\
\text { and 'slamming'cross members into position, and } \\
\text { from manipulating the 'anvil.' }\end{array}$ & $\begin{array}{l}\text { Have the conveyor deliver the rails onto } \\
\text { rollers that gradually rotates them upright. } \\
\text { The rails should also be delivered into } \\
\text { proper linear position but away from the } \\
\text { center. This will allow some cross } \\
\text { members to be placed onto stands in the } \\
\text { proper position before the rails are } \\
\text { delivered. Once the cross members are in } \\
\text { place the rails are mechanically pushed } \\
\text { towards the center for attachment. } \\
\text { Introduce a cross member delivery } \\
\text { system that will prevent having to lift the } \\
\text { cross members and other attachments out } \\
\text { of bins (Figure 1). } \\
\text { Improve anvil balancing and trolley } \\
\text { system. }\end{array}$ \\
\hline & Rear suspension hangers & \\
\hline
\end{tabular}




\begin{tabular}{||l|l|l||}
\hline $1-6$ & $\begin{array}{l}\text { Potential risk to hands, wrists, and shoulders from } \\
\text { repetitive lifting of hangers and handling of fastening } \\
\text { components. }\end{array}$ & $\begin{array}{l}\text { Introduce a parts delivery system that will } \\
\text { prevent having to reach and lift hangers } \\
\text { and other components out of bins or from } \\
\text { the middle of the conveyor. } \\
\text { Improve anvil balancing and trolley } \\
\text { system. }\end{array}$ \\
$\begin{array}{l}\text { Potential stress to lower back from leaning and } \\
\text { reaching into the middle of the conveyor to retrieve } \\
\text { certain fastening components. }\end{array}$ & $\begin{array}{l}\text { Potential risk to upper extremity and back from } \\
\text { manipulation of the 'anvil.' }\end{array}$ \\
\hline
\end{tabular}

Table 5 (Continued)

\begin{tabular}{|c|c|c|}
\hline & 1070 Station, Shock tower, Axle bracket & \\
\hline \multirow[t]{2}{*}{$1-5$} & $\begin{array}{l}\text { Potential risk to hands, wrists, and shoulders from } \\
\text { repetitive lifting of hangers and handling of fastening } \\
\text { components. } \\
\text { Potential stress to lower back from leaning and } \\
\text { reaching into the middle of conveyor to retrieve } \\
\text { certain fastening components. } \\
\text { Potential risk to upper extremity and back from } \\
\text { manipulation of the 'anvil.' }\end{array}$ & $\begin{array}{l}\text { Introduce a parts delivery system that will } \\
\text { prevent having to reach and lift the } \\
\text { hangers and other components out of bins } \\
\text { or from the middle of the conveyor. } \\
\text { Improve anvil balancing and trolley } \\
\text { system. }\end{array}$ \\
\hline & $\begin{array}{l}\text { Overlapping stations: } \\
\text { Toe hook/Bumper bracket/Huck stand } \\
\text { Rear engine bracket/Front rear hanger } \\
\text { Cab bracket tighten props and bracket }\end{array}$ & \\
\hline $1-6$ & $\begin{array}{l}\text { Potential risk to hands, wrists, and shoulders from } \\
\text { repetitive lifting and handling of attachments and } \\
\text { components. } \\
\text { Potential stress to lower back from leaning and } \\
\text { reaching into the middle of conveyor to retrieve } \\
\text { certain fastening components. } \\
\text { Risk to hands, torso area, lower back, and lower } \\
\text { extremity from having to lean and push against the } \\
\text { reamer while in operation. }\end{array}$ & $\begin{array}{l}\text { Introduce a parts delivery system that will } \\
\text { prevent having to reach and lift the } \\
\text { hangers and other components out of bins } \\
\text { or from the middle of the conveyor. } \\
\text { Develop a mechanism that will allow the } \\
\text { worker to position and press the reamer } \\
\text { onto the frame mechanically. This } \\
\text { mechanism could be similar to the setup } \\
\text { for nutrunners. }\end{array}$ \\
\hline & Minor repair & \\
\hline
\end{tabular}




\begin{tabular}{||l|l|l||}
\hline $1-4$ & $\begin{array}{l}\text { Potential risk to hands, wrists, and shoulders from } \\
\text { repetitive lifting and handling of attachments and } \\
\text { components. }\end{array}$ & $\begin{array}{l}\text { Introduce a parts delivery system that will } \\
\text { prevent having to reach and lift the } \\
\text { hangers and other components out of bins } \\
\text { or from the middle of the conveyor. }\end{array}$ \\
$\begin{array}{l}\text { Potential stress to lower back from leaning and } \\
\text { reaching into the middle of conveyor to retrieve } \\
\text { certain fastening components. }\end{array}$ & $\begin{array}{l}\text { Develop a mechanism that will allow the } \\
\text { worker to position and press the reamer } \\
\text { onto the frame mechanically. This } \\
\text { mechanism could be similar to the setup } \\
\text { for nutrunners. }\end{array}$ \\
\hline
\end{tabular}


Table 6

HETA 96-0101

Midland Steel Products Co.

Janesville, Wisconsin

Musculoskeletal stresses and recommendations for the Cross Member Fabrication area

\begin{tabular}{||l|l|l||}
\hline $\begin{array}{l}\text { Basic Job } \\
\text { froments } \\
\text { Table 2 }\end{array}$ & Problem & Recommendations \\
\hline \hline $1-8$ & $\begin{array}{l}\text { Potential risk to arms, shoulders, and lower } \\
\text { back from lifting, and carrying cross members } \\
\text { pieces from bins to the vise stand. }\end{array}$ & $\begin{array}{l}\text { Provide a bin with a spring loaded bottom on a } \\
\text { tilted platform. This type of bottom will raise } \\
\text { the pieces as the bin quantity decreases, } \\
\text { aleviating having to excessively lean into the } \\
\text { bin for piece retrieval. }\end{array}$ \\
$\begin{array}{l}\text { Potential risk to arms, shoulders, and lower } \\
\text { back from carrying finished cross members to } \\
\text { and placing them into a bin. }\end{array}$ & $\begin{array}{l}\text { Provide a conveyor system from the vise stand } \\
\text { to another bin for the finished product. This bin } \\
\text { should also be on a tilted platform and have a } \\
\text { spring loaded bottom. This type of setup } \\
\text { should aleviate the leaning and reaching when } \\
\text { placing the finished product into the bin. }\end{array}$ \\
\hline \hline
\end{tabular}




\section{Appendix A \\ HETA 96-0101 \\ Midland Steel Products Co. \\ Janesville, Wisconsin}

\section{Guidelines for Establishing a Plant Ergonomics Program}

There are seven basic elements needed to establish an effective ergonomics program: ${ }^{24}$ (1) Management commitment, (2) Labor involvement, (3) Training and education of management and labor on the principles of ergonomics, (4) Risk assessment of jobs through job analysis, (5) Medical surveillance to identify problem jobs, (6) Intervention or prevention applications to reduce or eliminate musculoskeletal disorders, and (7) Follow-up on the effectiveness of the intervention or prevention applications.

The first step in establishing an ergonomics program is development of an ergonomics team, making sure all personnel resources in the plant are represented, including management, labor, engineering, medical, and safety personnel. The team should establish a training schedule in which an outside expert, familiar with the plant operations, teaches ergonomic principles to management and labor. The written ergonomics program should also include provisions for risk assessment of hazardous jobs, implementation of controls (including budgets and a timeline), medical surveillance, and feedback from the workforce on the effectiveness of controls.

To document hazards and the effectiveness of controls, the workers' jobs may be videotaped before and after ergonomic changes are implemented. The videotape can be used for retraining experienced employees and as part of orientation for new employees. Evaluating medical surveillance records for changes in the incidence and severity rates can be used to evaluate the success of ergonomic interventions. Injury and illness rates should be determined by production rate, time of year, and age and gender of workforce.

A NIOSH technical report entitled Participatory Ergonomic Interventions in Meatpacking Plants ${ }^{25}$ highlights ergonomics program experiences from three different investigative groups at three different meat packing plants. The key findings included:

- Sustained participatory efforts in ergonomics problem solving will require strong in-house direction and support, plus significant staff expertise in both team building and ergonomics.

- Training in both team building and ergonomics can create the in-house knowledge and team activities reflecting an orderly approach to problem solving, and lays a strong foundation for a program.

- Team size should be kept minimal, but should include production workers engaged in the jobs to be studied, area supervisors, and maintenance and engineering staff who can effect proposed job improvements. Higher level management or labor representatives may also facilitate decision-making but their presence on teams may intimidate front-line workers and limit their input. These people may best serve on second level groups, providing oversight to the team activities and approvals of actions as may be needed.

- Effective team problem solving requires member access to, and sharing of, information bearing on the issues under study. In addition, reports on the team's objectives, progress, and accomplishments need to be circulated to the plant workforce to keep all parties informed about the program. Goals for the program need to be realistic and take account of the fact that solutions to some problems may not be immediately forthcoming. 
Appendix A (Continued)

Opportunities to address and solve simpler problems can build confidence in newly formed teams and provide positive motivations about undertaking the tasks involved.

- Means for evaluating team efforts and results need to be written into the overall plan for the participatory ergonomic program. Varied techniques exist for measuring aspects of team building and team function, the perceived level of effectiveness, and performance in both subjective and objective terms. Such data willenable the teams to appraise their progress, provide feedback to affected or interested parties, and make suitable corrections where necessary to improve the overall effort.

The two most important lessons learned from ergonomics programs are: (1) the program should not be created as an entity separate from the mission of the plant -- rather, it should be woven into existing programs such as safety and medical programs; and (2) the ergonomics programs must be sustained, as it is an iterative process that incorporates the philosophy of continuous improvement, transfer of technologies from one department to another, and documentation of ergonomic success and failures.

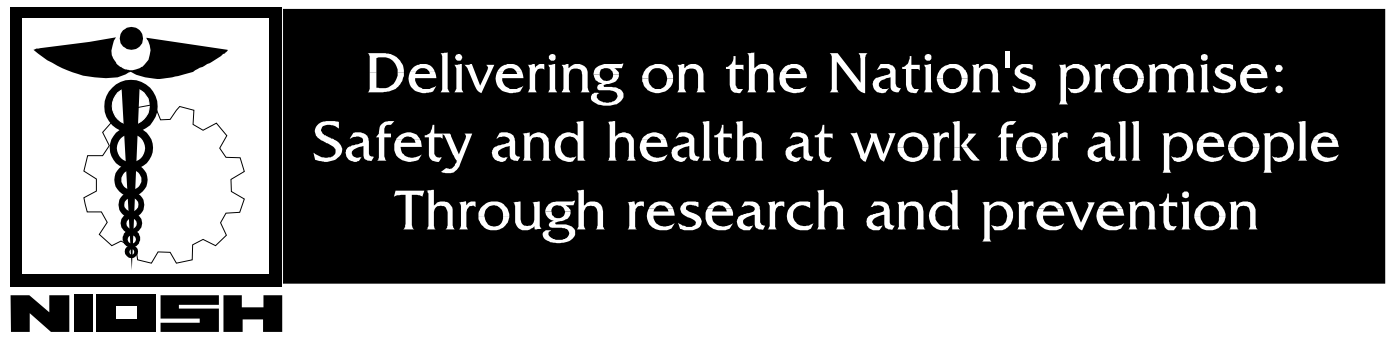

